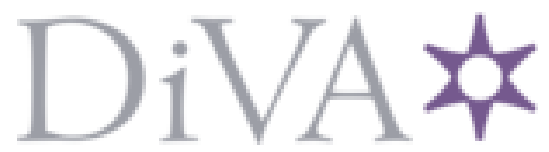

http://www.diva-portal.org

\title{
Postprint
}

This is the accepted version of a paper published in Communications: the European Journal of Communication Research. This paper has been peer-reviewed but does not include the final publisher proof-corrections or journal pagination.

Citation for the original published paper (version of record):

Kaun, A. (2012)

Mapping civic experiences in Estonia.

Communications: the European Journal of Communication Research, 37(3): 253-274

https://doi.org/10.1515/commun-2012-0014

Access to the published version may require subscription.

N.B. When citing this work, cite the original published paper.

Permanent link to this version:

http://urn.kb.se/resolve?urn=urn:nbn:se:sh:diva-16529 


\title{
DRAFT VERSION: submitted for consideration to \\ Communications: the European Journal of Communication Research (ISSN 0341-2059) \\ Mapping Civic Experiences in Estonia
}

\begin{abstract}
The article concerns civic experiences beyond or prior to civic action. Approaching questions of civic culture and democracy by way of the rather broad notion of civic experience, the author suggests that democratic values and processes involving citizens' participation should be understood as deeply anchored in the lifeworld. The article establishes a perspective in which civic culture is understood from a holistic perspective as an experience. At the same time, the author is interested in the ways in which media are involved in that process, without assuming their predominance in fostering civic engagement and public connection. Drawing mainly on 20 solicited, open-ended online diaries with young adults from Narva, Tartu, and Tallinn in Estonia and the European Social Survey Round 5, the article proposes civic experience as a helpful notion to overcome the generic divide between utopian and dystopian views on the relationship between media and civic culture.
\end{abstract}

Keywords: civic culture, mediated citizenship, young people, Estonia, online diaries 


\section{Mapping Civic Experiences in Estonia}

Research into civic engagement in connection with old and new media has flourished over the last decades, with new conceptualizations of citizenship continuously widening the understanding of civic engagement and involvement. To incorporate and understand new and alternative forms of engaging with politics and the public sphere, scholars have suggested notions such as do-it-yourself (Hartley, 2010), self-actualizing (Bennett, Wells, \& Rank, 2009), and unlocated citizenship (van Zoonen, Visa, \& Mihelja, 2010). These concepts, however often focus on action as the starting point for understanding citizenship as performance. This article proposes that civic experience is a notion that also encompasses non-action based engagement with the political, with politics, and with publics. The main aim is to propose civic experience as a concept for overcoming the typical divide between dystopian and utopian views of the potential that (new) media have for citizenship. Drawing on findings from a diary study and data from the European Social Survey Round 5 (in the following ESS) while focusing on civic engagement and participation in Estonia, the question driving the present analysis is in what ways civic experiences emerge in the participants' narratives and how these relate to media experiences in the context outlined above.

This article examines civic experiences beyond or prior to civic action in Estonia. Estonia, a relatively small country with approximately 1.3 million inhabitants, is situated in the north-eastern periphery of the European Union, bordering Russia to the east and Latvia to the south. As the perception of the public and politics can never be examined in isolation from the historical, socio-economic conditions in which they are situated, Estonia makes for an interesting case of historical division and tension. Currently, many of the existing tensions in the Estonian society are a result of the radical changes after the demise of 
the Soviet Union. The re-declaration of Estonian independence was accompanied by strong nationalistic movements on the one hand, and a strict normalization of neoliberal doctrine, on the other. A young and ambitious generation substituted the old Soviet elite on the political as well as media level at the beginning of the 1990s (Charles 2009; Lauristin \& Vilhalemm 2002). At the same time, the differences within in society grew. Marju Lauristin and Peeter Vilhalemm (2002) speak of winners and losers of the system change, whereby the losers did not receive much voice. The losers were, to a large extent, Russian-speakers based in the industrial north-east of Estonia. Historically-rooted tensions are still visible today and are reignited when symbolic points of reference are touched upon (e.g. the removal of the Bronze Soldier from Tallinn's city centre in 2007 and the erection of the new peace monument in 2009).

The article begins with a theoretical exploration of civic experiences. The developed definition of civic experience will be subsequently unpacked empirically, drawing on material from a larger research project that is dedicated to civic culture in Estonia. I then move on to an in-depth analysis of two diaries that represent extreme cases when it comes to civic experiences. The diary of one respondent, Kajsa, is richly interspersed with civic experiences. Her diary will be discussed at length in order to carve out the character of civic experiences in comparison to non-civic experiences, which are mainly represented in Helen's diary. Following the analysis, the paper ends with some conclusions.

\section{Theoretical Exploration of Civic Experiences}

In this article experiences are understood as both a stream of encounters (Erfahrung) and as disruptions to everyday life, and in that sense as specific, consummated episodes (Erlebnisse). ${ }^{1}$ The focus of this article, however, is on the latter, namely experiences as Erlebnisse. While the episodes in the diaries and the interviews are specific and concluded in

\footnotetext{
${ }^{1}$ For an in-depth discussion of the distinction see Turner $(1985,1986)$.
} 
their narrative form, they take shape against the background of a stream of experiences which are unspecific, which I call Erfahrung. In other words, Erfahrung is acquired over a citizen's lifetime; Erlebnisse are understood as citizens' concrete encounters, such as a taking part in protests. I focus on the latter in this article.

In general, my understanding of experiences resonates with Dewey's (1930/2005) arguments in Art as Experience. He describes an experiential situation as one where "under conditions of resistance and conflict, aspects and elements of self and the world that are implicated in this interaction qualify experience with emotions and ideas so that conscious intent emerges" (Dewey, 1930/2005, p. 36). They appear to be "the result of interaction between a live creature and some aspect of the world in which he lives" (Dewey, 1930/2005, p. 45). Experiences need "external embodiment" (Dewey, 1930/2005, p. 58), or some kind of articulation. In Dewey's case, the articulation or "external embodiment" takes shape in the art object. In the present case, experiences take shape in the participations' narrations, implying that there are different affordances or possibilities of structuring the external embodiment of experiences, rather like the work of art.

Experiences understood as Erlebnisse are related to different experiential objects ${ }^{2}$ (e.g., friendship, love, money, schools, peers) around which the narration and thereby the experience evolve. I am interested in experiences that evolve around the following objects: the political, politics, and citizenship. These experiences are consequently called "civic experiences," and refer to individual encounters of one's positioning in relation to others within the structures of democratic society. ${ }^{3}$ Furthermore, civic experiences become manifest when the individual relates to fellow citizens, that is, when a person negotiates his or her relationship with others who are linked in one way or another to the same regulative framework of rights and duties.

\footnotetext{
${ }^{2}$ Here I refer to not necessarily materialized objects of experience, such as passports (Gordillo, 2006).

${ }^{3}$ The structures here are not necessarily understood as congruent with the nation state. Other supra-national or global frameworks regulating the code of democratic conduct are conceivable as well, e.g., the European Union.
} 
The "civic" in civic experiences makes a link to the public, and not the private, character of the experiences that are of interest here. Dahlgren (2009) reminds his readers of the Greek (civitas) and the Latin (civcus) sources of civic. He argues that the civic is linked to the public. The civic is therefore apparent "in the sense of being visible, relevant for, and in some way accessible to many people, that is, situated outside the private, intimate domain" (Dahlgren, 2009, p. 58). He continues by defining the civic as something broader and as a precondition of the political.

The subsequently developed categories of civic experiences are based on Jones'

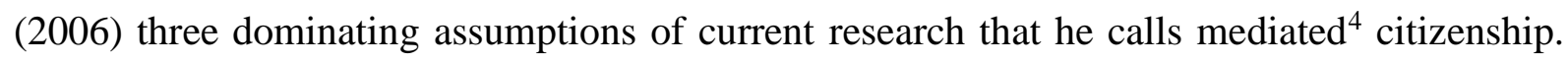
First, he argues that the research is dominated by the idea of hard news functioning as the major mediator between the political elite and the ordinary citizen. However, popular content may also play a similar role in mediation, as previous research has shown (Corner \& Pels, 2003/2006; van Zoonen, 2005; van Zoonen,Visa, Mihelja, 2010). Second, Jones argues, the analysis of political mediation often focuses on information dissemination for the "informed citizen" which, linking to Schudson (1999), is the normative expectation of the news media's contribution to political and civic culture. The third assumption about mediated citizenship is that political and civic engagement is based on and expressed through action. Jones asks, however important political action is, "what of the forces and factors that precede political action?" (Jones, 2006, p. 370, emphasis as in the original). He concludes that political and civic experiences are largely mediated, since "Western societies have experienced the explosive growth and diffusion of media technologies and their increasingly central location in our public and private lives" (Jones, 2006, p. 365). He further argues that "political activity comes, for most people, through their choosing, attending to, processing, and engaging myriad media texts about the formal political process of government and political institutions

\footnotetext{
${ }^{4}$ Mediated citizenship refers here to the involvement of media in the process of becoming and being a citizen: Jones, J. (2006).
} 
as they conduct their daily lives" (Jones, 2006, p. 378). A concept related to orientation is political interest, which is a crucial variable in political science. It has been mainly operationalized as the self-reporting of interest in elections or politics in general (Glenn \& Grimes 1968; McCombs \& Shaw 1972; Noelle-Neumann 1974; White, Bruce \& Ritchie 2000). One example of how interest in elections is measured can be seen in the following question: "Some people don't pay much attention to political campaigns. How about you, would you say that you have been/were very much interested, somewhat interested or not much interested in the political campaigns this year?" (Shani 2009; Teixeira 1992). What is missing here is an in-depth engagement with the diverse forms of orientation and how these evolve and develop in different contexts. Applying Jones' analysis of dominating paths in citizenship studies, this project follows the assumption that it is not necessarily news that is the mediator of political issues - the role model citizen is not imperatively the "informed citizen" (see also Schudson, 2003) and direct activity is therefore not presupposed. The understanding of the civic thus incorporates a broad variety of experiences that are both action and non-action related.

Based on the empirical material (diaries and interviews) gathered in connection with previous theoretical approaches (Jones, 2006), I distinguish between civic experiences that involve some kind of physical action and civic experiences that are mainly based on an orientation or involvement, namely a public connection. The first category encompasses civic experiences, such as civic participation, and includes a discussion of action-based civic experiences. The action-based civic experiences emerging in the diaries are analyzed in terms of Bennett's (2009) distinction between dutiful and self-actualizing citizenship. The second category of civic experiences resonates with Jones' critique of the traditional citizenship studies, which often exclusively conceive of civic experiences as action. Within this latter realm, I analyze civic experiences that appear as a public connection and which are non- 
action-based. The boundary between the two forms of civic experience is however not clearcut. Action-based civic experience and non-action-based civic experience often intersect and overlap. While non-action-based civic experience can lead to civic activities, they do not necessarily do so. At the same time, civic action resonates with non-action-based reflexive forms of civic experience.

Figure 1. Overview of civic experiences illustrating the conceptualization of civic experiences.

Furthermore, I will analyze and discuss civic experience as being mediatized, that is, being related to and moulded into experiences by media, which explicitly includes popular cultural media formats. Hepp speaks of the moulding forces of the media and argues that they need to be analyzed "in their netting with human action, especially (but not exclusively) with communicative action. Or one could say in the terms of a culturally oriented media and communication research: the specificity of media can only be articulated in their appropriation as a process of cultural localization. As materialized and institutionalised totalities of a plurality of (communicative) actions media only get 'powerful' in nettings with practices [...] this means moulding” (Hepp, 2011, p. 13). In a similar vein, the social anthropologist Hannerz (1990) argues that our lives are being made translucent (genomsyrad) by the media. Consequently, media experiences appear in connection with civic experiences, both as civic engagement and public connection.

\section{How to Investigate Civic Experience}

In order to develop an understanding of the potential that the media have to offer for civic experiences and the subjective perceptions of young adults about publics and politics, I have 
developed a multimodal research design combining both online and offline research. The project as a whole investigated specific aspects of young people's lives, which included finding out how these "people view the situations they face, how they regard one another, and also how they see themselves" (Hammersley \& Atkinson, 2007, p. 4). I attempted to get close to my participants' everyday lives without observing them directly, but by inviting them to produce narrations of their everyday experiences in the form of diaries and in-depth interviews. In this article, I focus on the diary material in order to carve out what civic experience means from an empirical perspective. ${ }^{5}$

Booth (1999) argues that as a research method, narratives have experienced a revival since the mid-1990s. This revival is due to the continuing importance of the Chicago School, as well as to feminist and critical race theory scholarship. Narrative methods are understood as way of making the voices of the oppressed and subaltern heard - in other words, the voices of those generally excluded from academic discourse. The second argument for narrative methods that Booth (1999) presents is that they are a way of overcoming the subordination of people's lives to the quest for generalization by researchers. Stories told by narrative methods reflect the emotional experiences of the storyteller, which are normally suppressed by socalled objective abstract methods.

The diaries produced in my study are best understood in terms of meaningful units that organize and structure the reflections and experiences of the participants in the form of stories. At the same time, they serve as disruptions of the stream of everyday activities and routines of the participants. Moores (2006) argues that analyzing the experience of migration, for example, provides an opportunity to research modes of disruption that might "heighten reflexive awareness." In a similar way, I understand the diaries as disruptions that are not as tremendous as a migration experience, but which are a break in established routines with the

\footnotetext{
${ }^{5}$ In addition to the diaries that were written in closed online wikis, 39 in-depth interviews were conducted with young adults of between the ages of 19 and 29.
} 
potential to trigger an enhanced awareness and reflexivity in the participants about their everyday lives. The narrations produced a temporary awareness of their own lives, as narratives are points for connecting individuals with their social surroundings. In this connection process, a multitude of voices are included and related to each other in the personal stories being told.

The participants were initially contacted through mailing lists at Tartu and Tallinn Universities, as well as at Narva College. In addition, I also presented my project at different occasions at the universities and recruited students directly. The project aimed at engaging not explicitly politically active students, but students with all kinds of interests and positions on the public and politics, similar to the approach of Couldry et al. (2007). The selection process, however, might have contributed to the self-selection of students that are more apt to express themselves in writing.

I cannot of course speak about young adults in Estonia in general, but about a specific group of students; the choice of participants also reflects the local specificities. Estonia was part of the Soviet Union from 1944 until it declared its independence on 20 August 1991. As a result of the migration politics during Soviet times (Raun, 2001), Estonia has a particular population mix. The region of Tartu differs to a great extent from Tallinn and also from Narva. Tallinn is characterized by a rather balanced spread of ethnic Russians and Estonians (55 percent Estonian, 36 percent Russian ${ }^{6}$ ), whereas Tartu is dominated by Estonian speakers (81 percent Estonian, 15 percent Russian). In Narva, in northeast Estonia, the population is mainly ethnic Russian (81 percent Russian, 4 percent Estonians). In order to capture these variations in ethnic patterns, I aimed to produce a quota sample mirroring that distribution. Furthermore, gender was an important sampling factor. Unfortunately, from the outset it was rather difficult to motivate male participants. Couldry et al., (2007) referring to

\footnotetext{
${ }^{6}$ Numbers from the last census in 2000, available at: www.stat.ee
} 
Elizabeth Bird (2003), state that women are more likely to feel comfortable about writing a diary. This is reflected in the slight gender bias when it comes to the low number of male diarists in my study. It is also clear that there was a lack of Russian diarists, something which is taken into consideration in the analysis.

The students were firstly asked to fill out a standardized questionnaire capturing their general media usage and socio-economic background. The questionnaire also asked about their commitment to participate further in the project. The students had the choice of an in-depth interview and/or a diary (online as well as offline). Of the more than 100 students who completed the questionnaire, 55 chose to continue, and of these 55,16 completed a diary, 35 took part an in-depth interview, and 4 did both as indicated in Table 1 . I aimed to include as many participants as possible while keeping the balance in terms of gender, ethnicity, and place of residence. In that sense, I was not following the saturation principle of continuous data gathering - gathering until no "new" information is found (O'Connor, Netting, \& Thomas, 2008) -but instead aimed to include as many unique voices as possible. The background characteristics of gender, ethnicity, and residence played a minor role in the analysis. They are not employed to explain variations in civic experiences. The focus of the analysis is on the civic experiences themselves, the larger categories they refer to, and their characteristics. The participants' backgrounds are employed to position the narratives of civic experiences in a context, namely the lifeworld of the participants.

\title{
Table 1
}

\author{
Socio-Demographic Facts concerning Participants of the Study
}

The analysis in this article presents different categories of civic experiences that have been developed based on previous research and the entire material gathered for this project. The illustrative examples in this paper however come only from the diaries. As for the concrete 
analytical steps, I followed Ricoeur's hermeneutic arc that describes the movements comprising the act of interpretation from the first reading and understanding of a text, to the structural analysis, and then to an in-depth understanding that is based on the explanatory structural analysis (Fornäs, 1995; Nygren \& Blom, 2001). At the same time, the analytical process incorporated movements between the empirical material and theories, as well as previous research. This movement is reflected in the analytical categories that are developed based on a dialogue between the analysis of the diaries, the interviews, and the theories. Both understanding and explanation, which constitute a general divide in academic research established by Dilthey, are therefore reconciled through the notion of an interpretation that is based on both explanation ${ }^{7}$ and understanding (Ricoeur, 1981). For my own analytical work, this meant I first had to read and grasp the meaning of the texts produced by my participants as a whole and then subsequently analyze them by means of a more structural approach to develop common themes and categories as they arose out of the material. ${ }^{8}$ The process of formulating the general and more specific categories that could be applied to all texts also took previous research and theories into account. Finally, the analysis culminated in the representation of the analytical categories in a story, in other words, an analysis that aimed at an in-depth understanding of the texts. I aimed to establish a holistic view at the material that followed the development of the different lines in the stories and took the contexts into consideration. My primary interest is however not the structure of the narrative, that is the characters and the beginning, climax, and ending (Ollerenshaw \& Creswell, 2002). The main interest here is in civic experience and its major characteristics.

The openness of the methods employed, which allowed for diverse civic experiences and their political effects, might be disputable. The aim of this article, however, is not to broaden the notion of the civic into meaninglessness, or to include all kinds of activities and

\footnotetext{
${ }^{7}$ However, in this article the focus is on mapping out civic experiences rather than explaining them.

${ }^{8}$ For an in-depth description of the analytical process including the identification of "text-based categories" and sensitizing concepts, see Auerbach (2003).
} 
orientations that involve, for example, creativity or fun as a means of countering citizen political withdrawal. Being political should still be understood as presupposing engagement. It involves struggles and taking unpopular positions to maintain and strengthen democracy. Civic experiences, as understood and analyzed here, do not occur automatically. Constant reenactment and re-examination of the struggles citizens relate to is required. In that sense, the "[p]olitical moral is no luxury that we can leave aside in case of emergency, but it is a crucial part of our live and survival strategy" (Negt, 2010, p. 560).

\section{Civic Experience as Civic Participation}

This section discusses forms of civic experience that are action-related and often considered as civic participation. Here one can distinguish between "conventional" and "nonconventional forms" of civic participation. Conventional forms of participation involve activities such as voting, party membership, signing petitions, attending legal demonstrations, and membership in non-governmental organisations. These forms of civic participation are often considered to be on the decline (Stolle, Hooghe, \& Micheletti, 2005), particularly among young people who are frustrated by the inaccessibility of the political sphere to which these practices relate (Long 2002). In general it could be argued that the practices subsumed within the category of conventional participation are mainly related to the sphere of politics that Mouffe (2005) distinguishes from the political, or as Verba and Nie suggest, civic participation refers to "activities by private citizens that are more or less directly aimed at influencing the selection of governmental personnel and/or the actions they take" (Verba \& Nie, 1987, p. 2, quoted in Bucy \& Gregson, 2001). In terms of the role of the media, conventional forms of civic participation are often linked to traditional mainstream media that function as information disseminators (Norris, 2000). The informed citizen is therefore the focus of this paper. 
Conventional civic practices can furthermore be mainly linked to dutiful citizenship. Dutiful citizenship implies one of two different ways in which citizens perceive and relate to the political sphere. Bennett et al. (2009) argue that the individualization linked to increasing reflexivity has caused a shift in how young people in particular engage with politics. They are "less inclined to feel a sense of duty to participate politically in conventional ways such as voting or following the news, while displaying a greater inclination to embrace issues that connect to lifestyle values, ranging from moral concerns to environmental quality" (Bennett, Wells, \& Rank, 2009, p. 106). The authors call the former dutiful citizenship (DC) and the latter (self-) actualizing citizenship (AC). Dutiful forms of civic participation refer to rather conventional forms of political activity, such as voting and party membership, whereas selfactualizing citizenship refers to non-conventional forms.

In contrast to conventional civic practices, some examples that have been suggested as forms of non-conventional civic participation include consuming fair trade and ecological products, "buycotts," recycling, being active in social and ecological movements or informal local groups, street art, the signing and forwarding of email petitions, and the ad-hoc organisation of protests (Sörbom, 2005; Stolle, Hooghe, \& Micheletti, 2005). These diverse forms of participation are often considered to be increasing among young people and are related, as Bennett et al.'s (2009) definition of self-actualizing citizenship suggests, to lifestyle questions. As non-conventional participation is often sporadic and individualized (Stolle, Hooghe, \& Micheletti, 2005), the new media in particular are considered to facilitiate such forms of participation (Bucy \& Gregson 2001; Hartley 2010; Jenkins 2006).

The boundaries between the conventional and non-conventional forms are of course not always clear-cut and conventional forms of participation such as voting might involve new, rather non-conventional features. However, this distinction seems to be analytically fruitful for the discussion of the diary material conducted in the project and in relating the 
findings to the European Social Survey (ESS). Stolle and Micheletti (2005) have noted that non-conventional forms of civic participation are often not systematically measured in larger surveys. The ESS, however, includes at least a number of variables referring to nonconventional participation (e.g., political consumerism).

In the diaries, the activities of conventional civic participation such as voting, party membership, or participating in any political forums such as city council meetings, are not as evident as non-conventional forms. There are three diarists who engage in a conventional sense, namely as party members, working for a political party during the campaign for local elections or voting in the same election. Siiri describes the point in time when she decided to participate in the election campaign as a significant moment of change:

Today I made a decision - I have to work for my future. So I decided to help one of the main candidates to win the election. I have never done it before. I'm little bit scared, but it is also very intriguing. So I think this is my challenge of the year. And I hope to learn so much from it. (Siiri - Diarist and Interviewee)

In general, the degree of conventional political participation in Estonia is rather low. Compared to other countries that are part of the $5^{\text {th }}$ Round of the European Social Survey (ESS), the low voter turnout in elections becomes particularly apparent. Whereas, in Estonia only 57 percent of the population participated in the last national election, the average for the ESS countries was 73 percent, as both reported in the ESS. When it comes to working for a political party, Estonia lies significantly below the average. In Estonia 3 percent of the respondents had been working for a political party or action group during the previous 12 months, compared to 12 percent among all ESS countries. However, in Estonia slightly more respondents than the EU average of 4.6 percent reported being a member of a political party 
(5.4 percent). If we take working for a civil society organization, signing petitions, and protesting as indicators for conventional civic participation, Estonia lies significantly below the ESS countries' average in all categories.

In contrast to the previous discussion, non-conventional forms of civic participation are characterized by participation in loose networks for social mobilization and action. In the diaries, forms of non-conventional civic participation range include applying to participate in an anti-racism music festival, forwarding petitions on online networks, developing political board games, commenting on online newspaper articles, volunteering in social organisations, as well as various forms of civic talk. Eleven out of the twenty diarists engaged in or reflected on at least one of the above-mentioned forms of non-conventional civic participation.

Some of the aforementioned cases might be interpreted as ambivalent or non-civic. For example, one could ask why playing at a music festival is understood as civic participation. Civic participation aims to change or preserve certain features within a political community (Adler \& Goggin, 2005; Bucy \& Gregson, 2001; Hooghe \& Stolle, 2004). In that sense, the will to change or establish counter-narratives to what is perceived as the failure to include marginalized groups in certain discourses is the focus of civic participation in the case of the music festival. The diarist presents participating in a music festival mainly in terms of the possibilities for the individual citizen to make a difference and perhaps change racist attitudes. In a similar way, the political board game is aimed at getting people involved in political discussions in a playful way.

Another difficult form of non-conventional civic participation might be civic talk. Dahlgren argues that "certain kinds of communicative competencies are important for a robust democracy" (2009, p. 86). Furthermore, he suggests that talk is constitutive for the public and is therefore a vital factor for democracy. Civic talk is among the basic foundations of the normative idea of deliberative democracy and is discussed as potentially triggering 
participation in more conventional terms (Klofstad, 2009). Civic talk, however, is not only of importance in the deliberative tradition, but also for radical democracy as suggested by Mouffe (1992, 1993, 2000, 2005). In Mouffe's terms it could be argued that the political emerges from conflictual talk between citizens as well as between citizens and the political elite, in which one side tries to convince the other or aims to establish an alternative, thereby countering the hegemonic discourse. Dahlgren (2009) describes this form of civic talk as talk with the potential to the political. As a second form of civic talk, Dahlgren (2009) suggests talk about politics as a sphere of ordering practices, discourses, and institutions that regulate human coexistence.

One example of civic talk with political potential is an episode Andres (diarist) describes:

\begin{abstract}
After the conference I went on an excursion in Narva with the foreign students. It was interesting for me to observe their behaviors and ways of thinking. What are Russian students like? What makes me different from them as a Russian student who lives in Estonia? ... We have talked about differences in our towns and they told me that Narva is much quieter and the streets are very clean and the roads are good. But this is of no importance for me. I asked what social problems they have. And they told me very calmly that they don't have any problems; this was surprising to me and also left me wondering. (Andres - Diarist)
\end{abstract}

At a university conference Andres engaged in a discussion with visiting students from Russia, as indicated in the quote above. Although he does not describe the situation of talk as primarily conflictual, there are clear tensions. The tensions arise between the idea he has about the life circumstances in Russia and the way the students present them to him, but they 
also relate to the divergent characters of Russians in Estonia and Russia. While this does not immediately appear to be conflictual, it does point to a conflict of self-identification and a question of belonging, and in that sense it has the potential to become political. The question of what Russianness means for him as an Estonian Russian is a re-appearing topic in his diary. It reflects the tensions of understanding and defining belonging to a certain community while feeling excluded from other communities. Andres tries to tackle these tensions by discussing them with students from Russia. In the discussion, his expectations and prejudices are countered, leaving him bewildered. This episode is understood as talk with a conflictual character, since it links back to persistent tensions between Estonians and Estonian Russians.

A striking example of talking about politics can be found in Kristjan's diary, which is almost entirely dedicated to narrations about the political sphere intertwined with the question of the mediation of current politics.

Recently I've been proding people I know concerning the upcoming European parliament elections. I'm totally amazed by the combined apathy, naivety, ignorance, and irresponsibility concerning the elections. ... Anyway, I'll try to do my best to also agitate folks around me. (Kristjan - Diarist)

In his diary Kristjan describes how he is trying to convince people to vote by talking about elections and the European Parliament, as he feels it is important to voice one's opinion through voting. His narrations of civic talk are talk about politics. However, this form of civic talk is also related to the political since it has a conflictual character, especially when he speaks of his aim to "agitate folks around" him.

Taking the broader picture into consideration, non-conventional political participation is quite uncommon in Estonia. If we take civic consumerism as an indicator for 
non-conventional forms of civic participation, Estonia's participation is 6 percent, significantly below the ESS average of 13 percent. Furthermore, when it comes to environmentally friendly lifestyles, including activities such as recycling waste and preferring sustainable transportation, Estonia lies below the EU27 average, as Keller and Kiisel (2009) show.

\section{Civic Experience as a Public Connection}

The notion of civic experiences as a form of public connection relates to a non-action-based orientation toward public spheres (Couldry, Livingstone, \& Markham, 2007). Civic experiences as a public connection are defined as being conflictual in character, since they are related to spheres where struggles about common concerns are taking place.

These forms of civic experience can, in certain times and under specific conditions, lead to action, but do not necessarily do so. They appear mainly as a form of interest and involvement at a pre-action based level. Civic experiences as a public connection can originate in private contexts, for example through relating private encounters to other individuals or media content in neutral public spaces, where they become civic experiences. In that context, mediatized civic experiences are of special importance, because media experiences might trigger or reinforce civic experiences as a public connection. In a similar context, Couldry et al. (2007) distinguish between media world connectors and public world connectors. Media world connectors relate mainly to the use of and reliance on media content to gratify an orientation toward a public sphere, whereas public world connectors choose other sources.

The diarist Jaan, for example, describes an encounter with reports about prisoners in Guantanamo. By choosing to write about this topic in his diary, he attributes a certain importance to it, not only in an individual but also in a broader sense, since he relates his situation to the media representation of Guantanamo prisoners by describing his personal 
experience, and puts them into the wider context of social relations with others after having read the news. The two dimensions of mediatized civic experience are addressed; that is, he relates a previously private experience to broader publics and the media content acts as the trigger for the experience.

I also remember that some time ago the newspapers wrote about Guantanamo and about some people who were apparently lost and transported to prisons were tortured in there. ... I would like to think that media has shown these things to be more terrible than they actually have been... I regret having read these articles from the newspapers as well. It would have been much easier to live without knowledge about these awful things. (Jaan - Diarist)

Mediatized civic experience might be linked to action-based civic engagement. In the diaries participants connect to practices and events such as voting and campaigning in the upcoming local elections, although they are not describing the performance of voting as such.

I watched the electoral debates of 2007 as well and had a bit of a laugh, to be honest. The people voting should be able to watch these videos, although Keskerakond [The Centre Party] is hiding them well by now. Of course, it's quite shitty, trying to explain why "We have to raise public sector salaries!", which then quickly turned into, "The public sector earns too much!" in only two years. Populism is an art, no doubt, but there's got to be someone to support it. (Pille - Diarist)

Pille was among those who wrote about casting a vote in the elections and also among those who quite frequently mentioned the election before it eventually took place. While writing 
about the elections, diarists like Pille mainly focused on the mediatization, that is on the television slots and the campaign clips on Youtube.

With the exception of one diarist, who was involved in the election campaign, all the diarists mentioned the elections and their mediatization. Moreover, they were rather critical, speaking of populism, manipulation, and chimaeras induced by the parties as well as by the mainstream news media and online portals. Kadri's diary entry provides an example of such criticism:

I will not vote for anybody because of good advertisements or because of the gimmicks that the parties offer. I hope that others around me also won't do this. Although I've heard about those who are easily convinced by the party that offers more good stuff. This kind of action is very bad. It is really stupid if people are ready to change their beliefs so easily (Kadri - Diarist).

In summary, the diaries are vivid accounts of both action- and non-action-based civic engagement, which resonates with other findings on civic engagement in Estonia. Institutionalized civic engagement with democratic structures is generally low in Estonia, which is also reflected in the diaries. Non-action-based civic experience expressed as a public connection is vividly described in numerous diaries, for example, in the form of media criticism. To get an in-depth picture of how one can understand civic experience from an empirical point view, I discuss two diaries at greater length in the following section.

\section{Civic Experiences versus Non-civic Experiences - Two Diaries}

In this section two diaries are presented to reveal the distinction between those diarists who mainly reflected on civic experiences, as opposed to diarists who mainly presented non-civic, 
private experiences. Like Couldry et al. (2007), I aim to illustrate the distinction by analysing two diaries so as to develop an idea about the diary material, the context, and the empirical expression of the theoretical categories developed above. The diaries are extreme cases in the sense that they are wholly dedicated to either civic or non-civic experiences, respectively. In contrast, the other diaries include both civic and non-civic episodes.

\section{Kajsa}

Kajsa is a 23-year-old Estonian student of social sciences in Tartu who is a heavy Internet media user. She stated that she uses the Internet for non-study and non-work-related purposes on average up to three hours a day. She never watches television, but reads one of the two national newspapers for up to one hour on an average day. Kajsa is mainly interested in animal rights issues and environmental questions. She however feels that political representation for the issues that interest her is missing in Estonia. Here she refers to the lack of a political party that focuses specifically on environmental questions. Furthermore, she misses non-governmental and local groups that are engaging with animal rights and environmental issues. The main problem, she argues, is the size of Estonia and the small number of people who are interested in these questions. Therefore, local green activist groups often depend on the enthusiasm and work of a single committed individual. If that person decides to quit working, the entire group falls apart. Her diary consists of narrations of civic experiences that range from discussions with her Facebook friends about a petition to pressure South-Korea to ban dog meat from the consumer market to a discussion about a new Estonian law on gay marriage. In a follow-up entry, she also discusses family values and traditions in Estonia and her own position on the questions of marriage and gay rights. Furthermore, she discusses the tremendous cuts in financial support from the state that Estonian students are faced with. However, there are no signs of taking action in terms of addressing the injustices she discusses in her diary, other than signing and sharing petitions. She was once member of 
an NGO and a volunteer in at wildlife organisation, but when she moved and started studying her engagement faded. Ever since, she has missed the activity and engagement in animal rights and environmental issues. However, she feels that it is too much of a burden to start her own activist group and, at the same time, keep up with her studies.

An example of conflictual civic experiences with fellow citizens is a specific episode in Kajsa's diary. She posted an animal rights petition on her Facebook page, prompting a series of arguments both for and against this petition. Her friends disagreed for various reasons.

In addition to her interest in animal rights issues, she is active in a group of approximately 15 to 20 bloggers who are basically writing for one another. They share entries about books and films as well as political ideas that cannot be found on established platforms and in the traditional media. They however keep this space closed by establishing the rule that new members have to be recommended by a group member. By doing so they establish a private public space, as she terms it, of an intense exchange of ideas and thoughts that is different from other discussion forums.

\section{Helene}

In contrast to Kajsa, Helene states that she is an average user of television, newspapers (online and offline), and the Internet. She is 26-years-old, Estonian, has just finished her studies in Tartu, and now works now as an assistant in a marketing office. The main difference between Kajsa's and Helene's diaries is that Helene almost never discusses any civic experiences. Her diary entries are dedicated to her travels, parties, money shortages, and partner. If she mentions popular cultural media content, she remains vague on her linkage to any broader conflictual issues beyond her private life. Clearly, the diary served a different purpose for her 
than it did for Kajsa. Helene uses it to reflect about her immediate emotional life, private relations, and life circumstances.

The non-civic nature of the experiences Helene describes relates to the fact that her diary consists of reflections that are constrained to her private life or, put another way, to the world of intimacy (Habermas, 1962). She does not relate her own precarious job and financial situation to broader issues such as the financial crisis and the government's austerity policies. She does not create linkages to other people or groups that suffer from similar difficulties, or show any kind of will to initiate counter-activities. She thus appears to be alienated from a wider sphere of negotiation; she discusses the problems that she faces as if they were unique to her. One episode in the diary where she reflects about her grandmother's attitudes is emblematic of the non-civicness of her experiences and her vagueness in connecting to public issues. She writes, for example, that her grandmother had difficulties in accepting that other people in her neighborhood benefited from social care and had received, among other things, a new washing machine. Helene thinks that this attitude is "shitty," but she remains unspecific as to why, for whom, and with what consequences this attitude is "shitty."

When it comes to the mediatization of civic experiences she is mainly disconnected; the media content is not set into a wider frame of negotiation on common issues. News is of especially little interest to her. While she points out that the reason for that disconnection lies within the character of current news reporting that is too negative and almost disgusting, she does not expand on that argument.

\section{Conclusion}

The article proposes civic experience as a rather general idea for understanding contemporary civic culture from the perspective of the citizens. The engagement with civic culture and its relation to the media can hardly be described as new or absent. The field is broad and everexpanding. With the growing interest in questions of mediatized democracy, the field - just as 
with many other areas - became fragmented, polarized, and contradictive. Reviews of the field tend to develop utopian versus dystopian views when it comes to the essential question of whether media contribute to a vivid civic culture or not. Driven by the experiences of the citizens themselves, this project has aimed to reflect the complexity of being political, relating to politics, and to fellow citizens. Although I am unable to provide definitive answers, the study opens up an alternative avenue for the investigation of civic culture.

Civic experiences that are of interest to this analysis have been defined as Erlebnisse, namely specific episodes in which the participants relate to and negotiate issues of common concern that emerge through reflections, more concretely in narrations. Erlebnisse in that sense are secluded episodes that stick out in the stream of the everyday. Barnhurst, quoting Husserl, writes that "people's experience of the world has these two aspects, a 'general indeterminate sense' and a 'sense determining itself according to particular realities"' (Barnhurst, 2003, p. 141). This quote reflects the divide between Erlebnisse, which are the focus here, and Erfahrung as experiences in a "general indeterminate sense." The latter form of experience encompasses long-term knowledge, identification, trust, practices, and values. In the context of civic culture, these Erfahrung are shared by a group of people in a specific cultural and historical context. Experiences as Erlebnisse are, by contrast, individual encounters that are made sense of through reflection transforming "mere" experience into an experience. For the realm of civic and political engagement I have suggested a distinction between civic experiences as Erlebnisse and civic culture as Erfahrung. The focus here has been on the subjective encounters, passions, and values that are actualized during and through civic action and orientation, resembling the idea of civic experiences as Erlebnisse that are embedded in civic culture as the foundation of civic life.

The article adopts an inductive approach that is guided by the experiences of the participants rather than by assumptions about specific media, such as for example, 
participatory discourse on new media, or forms of civic engagement that exclude non-actionbased orientation as civic experience. This approach is reflected in the research design of the project which proposed a combination of new and established methods for the empirical investigation of civic experiences. By way of applying this inductive approach, I have also proposed an alternative way of looking at the meta-process of mediatization that is currently the subject of intense debate, namely starting from lay persons' perceptions of both mainstream and alternative media in connection with their own civic experiences. Beginning with a methodologically open approach to civic and political engagement, the participants showed interest in and orientation toward public issues and public spaces. The participants created links to public issues by using diverse strategies. However, the institutions of representative democracy, such as parties and politicians, were rarely mentioned in their stories of public connection. Although the participants are engaging less with traditional politics, they are definitely political in the sense of being oriented to and participating in the negotiation of conflictual societal issues. For civic experience of a different kind, media and new media play an important role, albeit not the most important one. This puts the narratives of the participatory potential of new media, that were prompted for example by Jenkins (2006) and Hartley (2010), into perspective as well. Instead of assuming media dominance of the sense-making processes, this article has followed the complex process of "emploting" orientations to shared and negotiable concerns that, while embedded in media experiences, are not necessarily steered by them.

\section{References}

Adler, R. P., \& Goggin, J. (2005). What Do We Mean by "Civic Engagement"? Journal of Transformative Education, 3(3), 236-253.

Auerbach, C. (2003). Qualitative Data. An Introduction to Coding and Analysis. New York: New York University Press. 
Barnhurst, K. (2003). Subjective states: Narratives of citizenship among young Europeans. Multilingua, 22(2), 133-168.

Bennett, L., Wells, C., \& Rank, A. (2009). Young citizens and civic learning: two paradigms of citizenship in the digital age. Citizenship Studies, 13(2), 105-120.

Bird, S. E. (2003). The audience in everyday life: living in a media world. New York: Routledge.

Booth, T. (1999). Sounds of still voices. Issues in the use of narrative methods with people who have learning difficulties. In A. Bryman \& R. Burgess (Eds.), Qualitative research. (Vol. III, pp. 236-252). London, Thousand Oaks, New Delhi: Sage Publications.

Bucy, E., \& Gregson, K. (2001). Media Participation. A legitimizing mechanism of mass democracy. New media \& Society, 3(3), 357-380.

Charles, A. (2009). The Electronic State: Estonia's New Media Revolution. Journal of Contemporary European Research, 5(1), 97-113.

Corner, J., \& Pels, D. (2006/2003). Introduction: The Re-styling of Politics In: J. Corner \& D. Pels (Eds.), Media and the Restyling of Politics. Consumerism, Celebrity and Cynisism (pp. 1-18). London: Sage.

Couldry, N., Livingstone, S., \& Markham, T. (2007). Media consumption and public engagement: beyond the presumption of attention. New York: Palgrave Macmillan.

Dahlgren, P. (2009). Media and Political Engagement. Citizens, Communication, And Democracy. Cambridge, New York, Melbourne, Madrid, Cape Town, Singapore, Sao Paulo, Delhi: Cambridge University Press.

Dewey, J. (1930/2005). Art as Experience. New York: Perigee.

Fornäs, J. (1995). Cultural theory and late modernity. London: Sage.

Glenn, N., \& Grimes, M. (1968). Aging, Voting, and Political Interest. American Sociological Review, 33(4), 563-575.

Gordillo, G. (2006). The crucible of citizenship: ID-paper fetishism in the Argentinean Chaco. American Ethnologist, 33(2), 162-176.

Habermas, J. (1962). Strukturwandel der Öffentlichkeit. Untersuchungen zu einer Kategorie der bürgerlichen Gesellschaft. [The Structural Transformation of the Public Sphere] Neuwied: Luchterhand.

Hammersley, M., \& Atkinson, P. (2007). Ethnography: principles in practice (3. ed.). Milton Park, Abingdon, Oxon ; New York: Routledge.

Hannerz, U. (1990). Genomsyrade av medier [Translucened by media] In U. Hannerz (Ed.), Medier och kulturer [Media and Cultures] (pp. 7-28). Stockholm: Carlsson. 
Hartley, J. (2010). Silly citizenship. Critical Discourse Studies, 7(4), 233 - 248.

Hepp, A. (2011). Mediatization, Media Technologies and the 'Moulding Forces' of the Media. Paper presented at the International Communication Association Annual Conference.

Jenkins, H. (2006). Convergence culture: where old and new media collide. New York: New York University Press.

Jones, J. (2006). A Cultural Approach to the Study of Mediated Citizenship. Social Semiotics, $16(2), 365-383$.

Keller, M., \& Kiisel, M. (2009). Development tendencies of a consumer culture. In M. Lauristin (Ed.), Estonian Human Development Report (pp. 103-109). Tallinn: Eesti Koostöö Kogu.

Klofstad, C. A. (2009). Civic Talk and Civic Participation: The Moderating Effect of Individual Predispositions. American Politics Research, 37(5), 856-878.

Lauristin, M., \& Vilhalemm, P. (2002). The Transformation of Estonian Society and Media: 1987-2001. In P. Vilhalemm (Ed.), Baltic Media in Transition. (pp. 17-64). Tartu: Tartu University Press.

Long, S. (2002). The New Student Politics. The Wingspread Statement on Student Civic Engagement. Providence: Brown University.

McCombs, M., \& Shaw, D. (1972). The agenda-setting function of mass media. The Public Opinion Quarterly, 36(2), 176-187.

Moores, S. (2006). Media Uses and Everyday Environmental Experiences: A Positive Critique of Phenomenological Geography. Participations, 3(2).

Mouffe, C. (1992). Democratic Citizenship and the Political Community. In C. Mouffe (Ed.), Dimensions of Radical Democracy. Pluralism, Citizenship, Community (pp. 225-239). London, New York: Verso.

Mouffe, C. (1993). The return of the political. London ; New York: Verso.

Mouffe, C. (2000). The democratic paradox. London ; New York: Verso.

Mouffe, C. (2005). On the Political. New York: Routledge.

Negt, O. (2010). Der politische Mensch. Demokratie als Lebensform [The political being. Democracy as Lifestyle]. Göttingen: Steidl.

Noelle-Neumann, E. (1974). The Spiral of Silence. A Theory of Public Opinion. Journal of Communication, 24(2), 43-51.

Norris, P. (2000). A virtuous circle: political communications in postindustrial societies. Cambridge: Cambridge University Press. 
Nygren, L., \& Blom, B. (2001). Analysis of short reflective narratives: a method for the study of knowledge in social workers' actions. Qualitative Research, 1(3), 369-384.

O'Connor, M., Netting, E., \& Thomas, L. (2008). Grounded Theory: Managing the Challenge for Those Facing Institutional Review Board Oversight. Qualitative Inquiry, 14(1), 2845.

Ollerenshaw, J. A., \& Creswell, J. (2002). Narrative Research: A Comparison of Two Restorying Data Analysis Approaches. Qualitative Inquiry, 8(3), 329-347.

Raun, T. U. (2001). Estonia and the Estonians. Stanford, Calif.: Hoover Institution Press, Stanford University.

Reinsalu, K. (2009). The Implementation of Internet Democracy in Estonian Local Governments. Tartu: Tartu University Press.

Ricoeur, P. (1981). What is a text? Explanation and understanding. In J. B. Thompson (Ed.), Hermeneutics and the Human Sciences (pp. 145-164). Cambridge, MA: Cambridge University Press.

Ricoeur, P. (2007). Reflections on the Just. Chicago, London: The University of Chicago Press.

Shani, D. (2009). The origins of political interest. Princeton University, Princeton.

Schudson, M. (1999). The good citizen: a history of American civic life. Cambridge, Mass.; London: Harvard University Press.

Schudson, M. (2003). Click here for Democracy: A History and Critique of an InformationBased Model of Citizenship. In H. Jenkins \& D. Thorburn (Eds.), Democracy and New Media (pp. 49-59). Cambridge: MIT Press.

Stolle, D., Hooghe, M., \& Micheletti, M. (2005). Politics in the Supermarket: Political Consumerism as a Form of Political Participation. International Political Science Review, 26(3), 245-269.

Sörbom, A. (2005). När vardagen blir politik [When everyday becomes politics]. Stockholm: Atlas.

Teixeira, R. (1992). The Disappearing American Voter. Washington: Brookings Institution Press.

Turner, V. (1985). On the Edge of the Bush. Anthropology as Experience. Tucson: The University of Arizona Press.

Turner, V. (1986). Dewey, Dilthey, and Drama: An Essay in the Anthropology of Experience. In V. Turner \& E. Bruner (Eds.), The Anthropology of Experience (pp. 33-44). Urbana, Chicago: University of Illinois Press. 
van Zoonen, L. (2005). Entertaining the citizen: when politics and popular culture converge. Lanham, MD: Rowman \& Littlefield.

van Zoonen, L., Visa, F., \& Mihelja, S. (2010). Performing citizenship on YouTube: activism, satire and online debate around the anti-Islam video Fitna. Critical Discourse Studies, 7(4), 249-262.

White, C., Bruce, S., \& Ritchie, J. (2000). Young people's politics. Political interest and engagement amongst 14- to 24- year olds. London: National Center for Social Research.

Other sources

ESS Round 5: European Social Survey Round 5 Data (2010). Data file edition 1.0. Norwegian Social Science Data Services, Norway - Data Archive and distributor of ESS data.

Population Census 2000 (2000). Online Data Base. Statistics Estonia.

http://pub.stat.ee/px-web.2001/I_Databas/Population_Census/databasetree.asp.

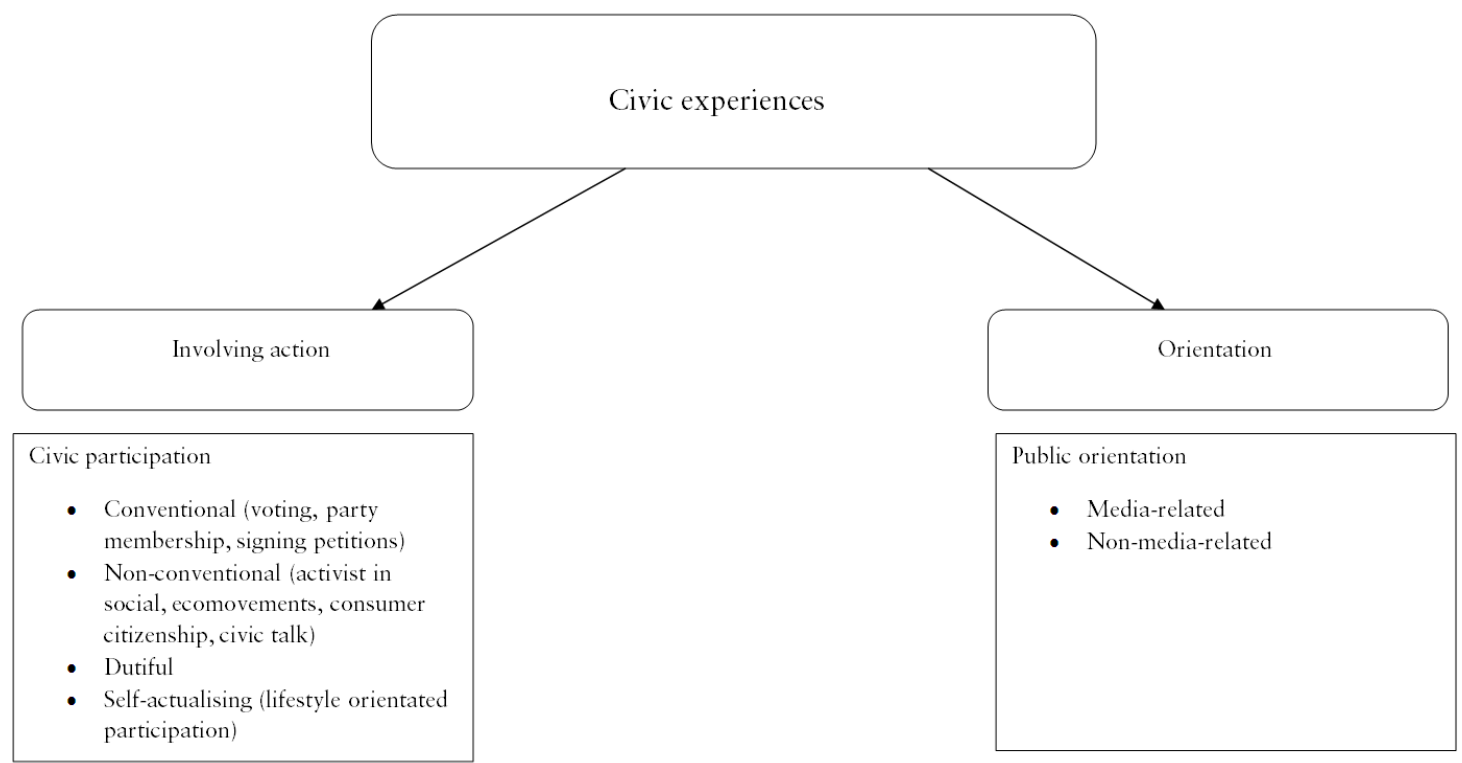

Figure 1. Overview of civic experiences, illustrating the conceptualization of civic experiences.

Table 1

Socio-Demographic Facts concerning Participants of the Study 
Female Male $\quad$ Tallinn $\quad$ Tartu Narva $\quad$ Estonian Russian Ukrainian

Diarists 13

7

$11 \quad 7$

2

17

1

2 